\title{
Quest for Skill-Based Health Education: The Historical Route
}

\author{
Anthonia U. Ejifugha, PhD \\ Department Of Physical And Health Education \\ Alvan Ikoku Federal College Of Education, Owerri, Imo State, Nigeria \\ Uwazie lyke Uwazie, PhD \\ Department Of Economics \\ Alvan Ikoku Federal College Of Education, Owerri, Imo State, Nigeria
}

\section{Doi:10.5901/mjss.2014.v5n26p168}

\section{Abstract}

\begin{abstract}
The paper traced the historical route of the quest for skill-based health education from the Hippocratic era to the contemporary society. At the root of every era in the development of health education is the means of conveying health practice. The route commenced with the Hippocratic era of presenting health knowledge as prescriptive to the era of Hygeia to the Renaissance period and the consequent invention of the printing machine that disseminated health knowledge with oral intercourse coupled with Cultural Revolution by visual artists. Hygiene eventually became a school subject because of its emphasis on preventive measures to avoid health problems. Health education was born because of the irrelevance of hygiene in changing health behaviour and practice. Various methods of teaching health education came to be but it was found that teaching health knowledge and attitude was not enough until individuals acquire and develop health skill as a way of life hence the introduction of skill-based health education. With the development of the 21 st century skills in many disciplines, health education has a task of delineating its skills in order to have a mapping of its conceptual framework.
\end{abstract}

Keywords: Hygiene, health instruction, health education, skill-based health education

\section{Introduction}

Education for health is a multifarious activity which many people engage in. It can be formal, informal or non-formal. It takes place in schools, communities, vehicles, hospitals, industries, national health education programmes and broadcasting media Formal aspect of education for health which is health teaching is described as health education. In pursuance of health teaching, different programmes evolutionarily emerged. Somer (1976) classified them into six: national health education, patient (health) education, occupational, school, community and media health education. Health education takes place in all these settings at any time a health need or problem is addressed. A health teacher or a resource person in health is required to disseminate health knowledge. One aspect of health education is the school health education programme

The premise of this study is that health education goes on in secondary schools in Imo State. The resource person prepared to teach health in schools is the school health teacher unfortunately, in the present day Nigerian secondary schools, the role of the school health teacher has been grossly undermined. Consequently, the teacher has not really influenced the adolescent's life style in matters relating to health. This contributes substantially to the in capabilities of adolescents to face health challenges and play their roles effectively in personal and community health.

School health education programme consists of health instruction, school health services, healthful school living, home school and community relations and school feeding services. Unfortunately in Nigeria, these components were not carried out as an entity but compartmentalized in schools where they exist. WHO (1992) in Okafor (2002) maintained that isolated health education sessions in schools were ineffective. Hence school health programme could not coordinate them as an entity. Adolescents exposed to skill- based health education will acquire skills that would see them throughout life.

As a universal concept health is highly appreciated and it is rated high among human values (Ziegler, 1975). Other values are character, social justice, skill, art, love, knowledge, philosophy and religion. Value denotes that property that indicates that something (objects, experience, event and, the like) is wanted or desired by persons because it is considered to be good (Holland \& Davis, 1975 in Ejifugha, 2003). Values are ideas and notions upon which worth is 
placed. They become internalized. They influence motivation, thought and behaviour. They turn out to become standards that guide ones behaviour and they are part of ones identity though individuals rarely realize how they influence their behaviour (http.www.answers.com.2010). Hence The historical route towards skill-based health education is the premise of this paper.

\section{The Journey towards skill-based health education: historical perspective}

Maintenance of optimal health has been a matter of concern to humanity all through the ages. Historically, the inability of man to meet the challenges of maintaining optimal health and curing diseases led to the consultation of deities. The god: Asclepius, in Greece was acknowledged by Homer to have superior knowledge of medicine. It had numerous temples in Greece that were consulted by many to receive healing or assurance of good health status which is technically described as optimal health.

The Asclepiad cult featured between 500BC-500AD and left a permanent legacy in the world of medical history which is the symbol of the staff of the physician. Adherents of this cult historically introduced the teaching of the principles of healthful living to their members (Lussier, 1984).

Hippocrates, the father of modern medicine, published his pioneering books on health and health matters. Some of such books were Aphorism and Regimen in health. These contained apt descriptions of health responsibilities to the infant, the athlete, the obese, the lean as well as on food and nutrition. This era was primarily dominated by prescriptive knowledge of health and healthful living which also corresponded with the art of medical practice in those days.

In the course of time, the Greek system of education came to play a part in the dissemination of the principles of healthful living to the populace. This was done through the teaching of gymnastics. The system taught lots of principles of healthful living. These included instruction on the care of the body, on bathing and dieting, the proper employment of labour and the advantages of labour through instruction on the principles of healthful living which was integral in Greek education. The system believed that optimal health was a matter of fate and not proper health management. Nevertheless, the Greek system of education introduced the concept of health instruction through the teaching of gymnastics.

For the Romans, the military officer must acquire knowledge of medicine as a part of his expertise. He needed the knowledge of medicine to physic his household which was made up of soldiers and retinue of slaves working in the farmland. The healthier the workforce, the more protected and more prosperous he was. He administered basic first aid when needed and his medical knowledge required administration of military surgery. These practices were disseminated through health instruction. The most prominent among them was Galen who introduced the concept of 'Hygeia' or 'De Samilate Tuende through his publications. He introduced the concept that the field of medicine has two parts: Hygiene and therapeutic. The former is to maintain health and the later to modify the conditions of the body (Charles 1959). Hence the concept of hygiene education came into existence.

Hygiene education was primarily based on acquisition and application of knowledge for the upkeep of personal health. This thrived over the years in Europe until the era of evolution of environmental sanitation led by Edwin Chadwick. Emphasis shifted to the knowledge of care of the physical environment and its deleterious influence on the health of man when mismanaged. Its direct influence on man was in relation with sanitation. Hence environmental sanitation became an aspect of education for health in Europe.

The same emphasis on the teaching of hygiene and environmental sanitation penetrated the United States through the activities of pioneers in this field of human endeavour in the state (Richard, 1962). In pursuance of personal health matters, the adverse influence on drugs, alcohol, and tobacco in the lives of youths in the United State led to the pressure to include them on as a unit of hygiene in schools. All these were taught under health instruction.

The didactic teaching of hygiene in schools which was embellished with the cramming of anatomical terms made hygiene unnecessarily irrelevant to personal health. Many professional bodies and pools of hygiene teachers began to agitate against the dryness of the teaching of hygiene in schools. The need to change from hygiene to a better concept that would make health knowledge relevant to human life and existence emerged. Consequently, the birth of health education as a discipline in the United States came to be in 1917. In other words, the method of teaching hygiene and its content became a challenge that birthed health education.

The evolution of health education in 1917 introduced an era of individual decision making in matters relating to health. This unpleasant situation led to the change from the didactic teaching of health knowledge to individual decision making on health matters. The decision must be informed consent based on adequate health knowledge of the subject matter. Since health education is a process of persuading people to take informed decision about health and health related matter, the methods and techniques of persuasion became very significant and indispensable. Over the years, 
various strategies have been evolved to persuade people and equip health educators in bringing about positive changes in health behaviour.

In the United States, the realization of the need to equip teachers with teaching methods, and techniques compelled the Joint Committee on Health Problems in Education of the National Education Association to issue charts and pamphlets to classroom teachers (Lussier 1984, and Means 1975). The course titled methods and materials for health instruction was very much promoted by Caroline Brag that it received very significant attention in teaching health instruction. Teachers who were trained in health contents to be taught in schools thereafter went for additional carrier knowledge in methods and materials in health education (School Health Bureau, 1955).

Health education came into the Nigerian Educational System as Hygiene and Sanitation in 1882 amidst other school subjects (Mkpa 1987). In the early years of hygiene and sanitation in schools in Nigeria, initial difficulties were encountered. The Director of Education, Southern Provinces Lagos, through a memorandum called for suggestions on how to improve the teaching of hygiene in Nigerian schools. The focus was on these areas:

1. The teaching of hygiene in schools, the best approach for Nigerian children;

2. The formation of school clinics, and

3. Sanitary arrangements in school compounds (Ministry of Education 1928) and (Ministry of Education, 1933).

Additionally and most significantly also the above report from the Ministry of Education in 1928 introduced the three traditional components of the school health programme as an entity originating from the Ministry of Education.

Generally, it was observed that the teaching of hygiene in government and assisted schools was to a great extent very perfunctory. There were more emphasis on the theoretical aspect of hygiene than on the practical; theory and practice were not linked. The memorization of difficult technical terms was the mode of teaching (Supritendent of Education Calabar Province, 1933). Hygiene was also observed to be notoriously one of the worst subjects taught in schools so lectures to teachers by medical officers of health would do much good. (Grier, 1977).

The need to change from hygiene to health education arose as a result of the method of teaching hygiene in schools and the content of instruction as reported by Boucher (1927) and (Grier 1927). Originally in many countries, the content areas of hygiene were inadequate for the promotion of healthful living (1version 1981 and Grain 1985). These deficiencies necessitated the introduction of the terminology; health education, in order to shift emphasis to the principles of healthful living.

In 1948, the term health education was introduced in Nigeria as one of the school subjects in the southern provinces to replace hygiene. A syllabus for physical and health education emerged in 1950 for teacher training colleges (Ministry of Education, 1950) and (Ejifugha 1999).

\section{Skill-Based Health Education}

The roles of the health teacher encompass skill-based health education; health services and healthful school living, school feeding services and home, school and community relationship. The contemporary role of the school health teacher is the inculcation of health knowledge which is distinct from health practice.

This lapse in the professional role of the health teacher at the secondary school is demonstrated by lack of confidence in late adolescents in handling health problems facing them. Some reported cases of health problems in medical centres in tertiary institutions such as, fungi infection; malaria, diarrhoea, etc. are few examples of disease that are arrested by preventive health measures. If the school health teacher has done a good job in teaching the behavioural components of these preventable health problems, the adolescents would have been very conscious of this and they would have consequently prevented the occurrence of such health problems. The technical know -how of communicating health knowledge in order to bring about change in health behaviour has depended largely on the art of communicating the scientific basis of health behaviour.

For any health problem a child experiences at home, the parent is most often the first port of call; this should be the case at school. A health teacher should be the first to be informed of any symptom of health problems by any child in school. Not only that the school health teacher should teach students to take appropriate health action, but should ensure that health education generates the need to be skill-based. Health problem can be physical, social, mental or emotional. These demand the attention of the school health teacher. It is anticipated by his/her professional qualification to be able to provide health counseling when it is required or as circumstance may demand. In other words, a health teacher is employed not only to literally teach health education in school but also to pay attention to individual students to identify their health problems and needs. This role demands friendship from the health teacher towards the students. If they confide in him or her for scientific health counseling, many health problems of adolescents could be alleviated particularly the social, mental and emotional problems. It is the health teacher in his/her cordial relationship with students, who will be 
able to handle this onerous task of influencing the lives of this volatile group before their health behaviour could be consolidated at late adolescence. This requires social and health skills.

The apparent lack of effective role of the health teacher in the school is evidenced by environmental nuisance experienced all over the country in form of indiscriminate dumping of refuse. A child in primary school, under the watchful eyes of the class teacher, may not drop refuse as anyhow in the school premises for fear of punishment. There are also sanitary activities such as sweeping the class every morning, picking solid waste, sweeping and washing toilets etc. The situation is completely different in our secondary schools particularly day schools. Strict discipline is lacking in matters like these students still urinate at any convenient corner of the school premises; this demands urgent need for skill-based health education as a way of life.

\subsection{Objectives of Skill-Based Health Education}

i. To comprehensively delineate the skills to be acquired through health education for health promotion of the school community.

ii. To teach and inculcate the skills in the learners.

iii. To train the school health teacher to first possess the skills and inculcate same to the learners.

iv. To monitor the development of these skills in the learners, motivate and reinforce those who perform well in this regards.

v. To develop skill-based health education curriculum for the training of teachers and learners.

vi. Evaluate learners' progress towards healthy development in the acquisition of health skills.

\subsection{Elements of Skill-Based Health Education}

- The curriculum ie teacher and pupil activities.

- Teacher and development of learning materials.

- Infrastructure - provision of facilities and equipment which encourage appropriate skill development.

- Personnel - health education teachers, head teachers/principals and other trained staff that will give support to acquisition of health skills. (Federal Ministry of Education, 2006).

With the introduction of these elements and objectives, skill-based health education has come to be a recent phenomenon in the Nigerian school system.

\section{Background of the 21 st century skills}

The 21st century skills" and "college and career readiness" have recently become watchwords in education. The Partnership for 21st century skills advocates adoption of local, state, and federal policies that support explicit integration of 21st century skills into instruction for all students. The two consortia formed in response to Race to the Top both highlight college and career readiness as their primary educational target. Furthermore, the Common Core State Standards anchor K-12 academic standards in expectations that all students will be college-or career-ready upon high school graduation (Lai and Viering, 2012)

Along with new emphases on including 21st century skills in curricula and instruction is a growing need to assess students' competency at these skills on a large scale. Accordingly, recent policy initiatives have contributed to conversations about attributes of so-called "next generation" assessment systems. For example, according to the Partnership for Assessment of Readiness for College and Careers (PARCC) consortium, assessment tasks must "measure rigorous content and students' ability to apply that content. Such tasks will "elicit complex demonstrations of learning and measure the full range of knowledge and skills necessary to succeed in college and 21st-century careers. Additionally, these tasks will send a strong, clear signal to educators about the kinds of instruction and types of performances needed for students to demonstrate college and career readiness.

\subsection{Which 21st Century Skills?}

Although these skills are not new, it was not until very recently that educators and policy makers agreed that they should be explicitly included in academic content standards, directly taught alongside the regular academic curriculum, and routinely assessed for all students. Despite widespread agreement on their importance, however, there still appears to be 
disagreement as to which particular skills matter for college and career readiness. Numerous skills frameworks exist and different frameworks identify different skills as important. For example, the Common Core State Standards (CCSS) in English Language Arts specifically call for instructional emphasis on "application of knowledge through higher-order skills," such as the ability to create and support arguments based on evidence and logical reasoning through writing and sharing ideas with classmates via speaking and listening during informal collaboration.

The Partnership for 21st Century Skills (P21) has created a comprehensive framework for conceptualizing different types of skills important for college and the workforce. For example, learning and innovative skills include creativity and innovation, critical thinking and problem solving, and communication and collaboration. Information, media, and technology skills include information literacy, media literacy, and information/communications/technology literacy. Finally, life and career skills include flexibility and adaptability, initiative and self-direction, social and cross-cultural skills, productivity and accountability, and leadership and responsibility (Partnership for 21st Century Skills, 2009). Obviously skills for health became an integral component of the $21^{\text {st }}$ century skills.

The National Research Council initiated an investigation into the topic of teaching and assessing 21st century skills, hosting several workshops and seminars beginning in 2005. Out of this work came a framework for categorizing the types of knowledge and skills students need for college and career readiness: (1) cognitive skills, including critical thinking, non-routine problem solving, and systems thinking; (2) interpersonal skills, including complex communication, social skills, teamwork, cultural sensitivity, and dealing with diversity; and (3) intrapersonal skills, including selfmanagement, time management, self-development, self-regulation, adaptability, and executive functioning (Committee on the Assessment of 21st Century Skills, 2011).

Finally, the Assessment and Teaching of 21st Century Skills (ATC 21) organization has also offered a framework for organizing different types of 21st century skills (Binkley et al., 2010). This framework includes four classes of skills:

1. Ways of Thinking, which encompass creativity and innovation; critical thinking, problem solving, and decisionmaking; and meta-cognition or learning to learn.

2. Ways of Working, which includes communication and collaboration or teamwork.

3. Tools for Working, which addresses information literacy and information and communication technology (ICT) literacy.

4. Living in the World, which includes citizenship, life and career skills, and personal and social responsibility. The content of these is demonstrated in the table below.

Table 1. Mapping of 21st Century Skills Frameworks Research-Based Construct

\begin{tabular}{|c|c|c|c|}
\hline $\begin{array}{l}\text { Table 1. Mapping of 21st Century Skills } \\
\text { Frameworks Research-based construct }\end{array}$ & P21 Framework terminology & NRC Framework terminology & ATC 21 Framework terminology \\
\hline Critical thinking & $\begin{array}{l}\text { Learning and innovation - critical } \\
\text { thinking }\end{array}$ & Cognitive - critical thinking & $\begin{array}{l}\text { Ways of thinking - critical thinking, } \\
\text { problem-solving, and decision-making }\end{array}$ \\
\hline Collaboration & $\begin{array}{l}\text { Learning and innovation - } \\
\text { communication and collaboration }\end{array}$ & \begin{tabular}{|llr} 
Interpersonal & - & complex \\
$\begin{array}{l}\text { communication, } \\
\text { teamwork }\end{array}$ & social & skills, \\
\end{tabular} & $\begin{array}{l}\text { Ways of working - communication and } \\
\text { collaboration }\end{array}$ \\
\hline Creativity & $\begin{array}{l}\text { Learning and innovation } \\
\text { creativity and innovation }\end{array}$ & $\begin{array}{l}\text { Cognitive - non-routine problem } \\
\text { solving }\end{array}$ & $\begin{array}{l}\text { Ways of thinking - creativity and } \\
\text { innovation }\end{array}$ \\
\hline Motivation & $\begin{array}{l}\text { Life and career skills -initiative, } \\
\text { flexibility }\end{array}$ & $\begin{array}{l}\text { Intrapersonal - self-development, } \\
\text { adaptability }\end{array}$ & $\begin{array}{l}\text { Living in the world -adaptability, } \\
\text { flexibility, self-direction }\end{array}$ \\
\hline Meta-cognition & $\begin{array}{l}\text { Life and career skills - self- } \\
\text { direction, productivity }\end{array}$ & $\begin{array}{l}\text { Intrapersonal - self-management, } \\
\text { self-regulation }\end{array}$ & $\begin{array}{l}\text { Ways of thinking - meta-cognition or } \\
\text { learning to learn }\end{array}$ \\
\hline
\end{tabular}

Within this framework, health education seeks to identify its role in identification of skills that promote health. Decision making for instance is a life skill which is one of the core skills of health education..Ways of Thinking, Ways of Working, Tools for Working and Living in the World. These mappings of the $21^{\text {st }}$ century framework fall within the domain of mental health, occupational health, physical, emotional, mental health and social health.

Critical thinking, collaboration, creativity, motivation and meta- cognition are inherent terminologies in health education from which skills for health could be derived. HenceHealth Education as a discipline is in the race for search for delineation of skills as a recent development in the field of health by World Health Organization.

\section{Conclusion}

The paper has presented the historical route of the quest for skill-based health education in Nigeria, commencing from 
the Hippocratic era to the period of Galen the father of hygiene. From the medical era prescriptive knowledge of health practice was administered while Galen through his work on hygiene introduced preventive medicine. The Greek pattern of teaching was based on health instruction but they were fatalistic in their approach towards health teaching through gymnast ics. The Roman noble gentlemen followed the same pattern in administering first aid to their soldiers and household. The period of renaissance invented printing and extended prescriptive knowledge of health to all literates. Cultural force came through oral intercourse of health information and the use of audio and visual media. Sculptural artists played their part while mountebanks and charlatans demonstrated the body system and the occurrence of diseases.

Eventually hygiene became a school subject that would influence health behaviour but the didactic approach of teaching it called for the need to change from Hygiene to health education. Health education came in with emphasis on personal decisions on matters relating to health. This integrally demanded methods and materials to convey the existing health knowledge even in Nigeria..Very recently the move to change from health instruction to skill-based health education became very obvious in Nigeria.

\section{References}

Boucher, H. (1927). Memorandum to the director of education southern provinces. Teaching of Hygiene in School. Ministry of education, Enugu (MINED) 7/1/6. DE 640

Binkley, M, Erstad, D., Herman, J., Raizen, S., Ripley, M., \& Rumble, M (2010). Defining 21st Century Skills: Assessment and Teaching of $21^{\text {st }}$ Century Draft white Paper. The University of Melbourne, Australia

Charles, J. (1959). Health education in classical Greece and Rome. The Health Education Journal, 17 (1), 2-10

Committee on the Assessment of 21st Century Skills, (2011) Assessing 21st Century Skills: Integrating Research Findings. National Council on Measurement in Education, Vancouver, B.C., Canada

Emenalo E.C. (2004). Parasitic disease the source of mankind. The Peacemaker Alvan Ikoku College of Education, Owerri.

Ejfugha, A.U. (2006). Equipping the health teacher. Owerri: Danny Publishing Company.

Federal Ministry of Education (2006 Dec). Implementation guidelines on National School Health Programme (Draft)

Gains, J. (1985). Health education content and assessment. Health Education,15(6), 7-8

Grier, S.M. (1927). Memorandum to the Director of Education Southern provinces. Teaching of hygiene in school .Ministry of Education, Enugu (MINED) 7/1/6. DE 640

Iverson, D.C. (1981). Promoting health through schools. A challenge for the eighties. Health Education Quarterly, 8(1)6-8

Lai, E.R. \& Viering, M (2012) Assessing 21st century skills integrating research findings Canada. National Council on Measurement in Education, Vancouver, B.C. pg 25-28

Lussier, R. (1984). History of health education. In R. Rubison and W.F. Alles (Eds). Health education and foundation for the future (pp 324). St. Louis: Times Mirrow/Mosby College Publishing

Means, R.K. (1975). Historical perpecptives on school health. New Jersey: Charles B. Slack.

Ministry of Education (1928). British social hygiene council. Teaching of Hygiene in school, 1, Enugu (MINED) 7/1/6. DE 640

Ministry of Education (1933). Memorandum to the Assistant Director of education Southern provinces. Teaching of hygiene and sanitation in southern province, 11 .Ministry of Education, Enugu (MINED) 7/1/6. DE 640

Ministry of Education (1950). New Syllabus for award of the teacher's higher elementary certificate. Zaria: Gaskya Corporation.

Ministry of Health (1933). School medical and health services. MOH 108. National Archives Enugu, Enugu State, Nigeria.

Mkpa, M.A. (1987). Curriculum development and implementation. Owerri: Totan Publishers.

Obafemi Awolowo University, lle-Ife, Nigeria in collaboration with UNICEF Training Manual for short course on school health programme (Draft)

Okafor R.U. (2002). A comprehensive approach to implementing health education through churches. Nigeria School Health Journal Eastern Zones 3 (1), 34-4

Partnership for 21st Century Skills (2009). P21 Framework. Definitions. Retrieved from http:/www/p21.org/storage/documents /p21Framework Definitions. pdf

Richard, K.A. (1962). A history of health education in the United State. Philadelphia: Lea and Febiger

Somer, A (1976). Promoting health: consumer education and national policy. Mary Island; aspen.

Udoh, C.O. Fawole, J.A. Ajala J. Nwana. O.C. and Okafor, F. (1987), Fundamentals of health education. Ibadan, Heinemann Educational Series

Ziegler, E.F. (1975). The health teacher needs a philosophy. In D.A. Read (ed). New direction in health education: some emergency contemporary issues for the emerging age. New York: Macmillan. 